HORIZON 7 (1) 2018 : II. Book Reviews : Prepared by I. Apostolescu : 240-246

ФЕНОМЕНОЛОГИЧЕСКИЕ ИССЛЕДОВАНИЯ • STUDIES IN PHENOMENOLOGY • STUDIEN ZUR PHÄNOMENOLOGIE • ÉTUDES PHÉNOMÉNOLOGIQUES

https://doi.org/10.21638/2226-5260-2018-7-1-240-246

\title{
SARA HEINÄMAA, MIRJA HARTIMO, TIMO MIETTINEN (EDS.) PHENOMENOLOGY AND THE TRANSCENDENTAL Routledge, New York (Research in Phenomenology, Vol. 1), 2014. ISBN 978-0-415-86988-1
}

\section{IULIAN APOSTOLESCU}

PhD Student.

University of Bucharest, Faculty of Philosophy. Phenomenological Reviews, Co-Editor-in-Chief. 021232 Bucharest, Romania.

E-mail: iulian.apostolescu@gmail.com

What can phenomenological reflection contribute to the ongoing discussion of transcendental thought? What kind of transcendental philosophy is phenomenology? Why does Husserl's unfinished project merit the name transcendental? Can the notion of transcendental phenomenology be defended today, and is Husserl right in insisting upon its uniqueness and indeclinability? To what extent is the very idea of transcendental phenomenology deeply committed to metaphysical prejudices that we have to renounce the transcendental project in favour of other projects? To what extent is speculative realism in a position to overcome the Kantian philosophical framework? This impressive collection of essays is a lucid, insightful and important attempt to answer these questions. Not only does it give new insight into the transcendental character of phenomenology, but it also outlines the dynamic development of phenomenology as a continuing and expanding domain of research. The editors claim that this volume "is motivated by the insight that the novel interdisciplinary situation in which phenomenology conducts fruitful exchanges with several empirical sciences demands that we reconsider thoroughly the fundamental methodological questions concerning the transcendental character of phenomenological inquiries. Phenomenology and the Transcendental brings together original articles that together clarify the transcendental aspects of phenomenology and outline new transcendental versions of phenomenology in distinction from the naturalistic, vitalist, and poststructuralist approaches that dominate philosophy at the moment" (p. 3). In this review, I provide a brief overview of the contributions to this volume to show how the transcendental standpoint is indispensable for genuine phenomenology and philosophical reasoning in general.

Key words: Transcendental, phenomenology, subjectivity, world, Kant, Husserl, Heidegger.

(C) IULIAN APOSTOLESCU, 2018 
РЕЦЕНЗИЯ НА КНИГУ:

САРА ХЕЙНАМАА, МИРЬЯ ХАРТИМО, ТИМО МИЕТТИЕН (РЕД.)

PHENOMENOLOGY AND THE TRANSCENDENTAL

Routledge, New York (Research in Phenomenology, Vol. 1), 2014.

ISBN 978-0-415-86988-1

\section{ЮЛИАН АПОСТОЛЕСКУ}

Аспирант.

Университет Бухареста, факультет философии. Со-редактор журнала Phenomenological Reviews.

021232 Бухарест, Румыния.

E-mail: iulian.apostolescu@gmail.com

Какой вклад феноменологическая рефлексия может внести в текущую дискуссию о трансцендентальной мысли? Какого рода трансцендентальную философию представляет собой феноменология? Почему незавершённый проект Гуссерля заслуживает наименование «трансцендентальный»? Можно ли сегодня отстоять понятие трансцендентальной феноменологии, и прав ли Гуссерль в том, что настаивает на её уникальности и неизбежности? В какой мере и насколько глубоко сама идея трансцендентальной феноменологии нагружена метафизическими предпосылками; ведёт ли это к тому, что мы должны отказаться от трансцендентального проекта в пользу других форм рефлексии? В какой мере спекулятивный реализм способен преодолеть кантовскую философскую концептуальную рамку? Этот впечатляющий сборник статей представляет собой ясную, содержательную и значимую попытку ответа на эти вопросы. В сборнике не только представлены новые идеи, затрагивающие трансцендентальный характер феноменологии, но также намечается динамическое развитие феноменологии как непрерывно расширяющейся области исследования. Редакторы сборника исходят из того, что «новая междисциплинарная ситуация, в которой феноменология продуктивно взаимодействует с рядом эмпирических наук, требует исчерпывающего пересмотра фундаментальных методологических вопросов, касающихся трансцендентального характера феноменологических исследований. Феноменология и трансиендентальное объединяет ряд оригинальных статей, которые вместе проясняют трансцендентальные аспекты феноменологии и намечают новые варианты трансцендентальной феноменологии, в отличие от натуралистических, виталистических и постструктуралистских подходов, господствующих на данный момент в философии» (с. 3). В данной рецензии я предложу краткий обзор статей этого сборника, с целью показать насколько трансцендентальная позиция неотъемлемо присуща подлинной феноменологии и вообще философскому рассуждению.

Key words: Трансцендентальное, феноменология, субъективность, мир, Кант, Гуссерль, Хайдеггер.

In recent years, several books dedicated to various possible approaches to the horizon of phenomenological transcendental philosophy have been published ${ }^{1}$. We have witnessed also a resurgence of scholarly interest in post-Kantian idealism and in

1 See, for example, Dan Zahavi (2017); Chad Engelland (2017); Jairo José da Silva (2017); Phillip Honenberger (2016); Sebastian Gardner, Matthew Grist (2015); Andrea Staiti (2014); Sebastian Luft (2011). 
transcendental modes of philosophical inquiry ${ }^{2}$. In contrast to many other books of this kind, Phenomenology and the Transcendental doesn't strike the reader as an eclectic collection of relatively independent contributions. On the contrary, this groundbreaking volume provides new and important insights into the "indispensability of the transcendental standpoint for phenomenology and philosophical reasoning in general" (Heinämaa, Hartimo, Miettinen, 2014, 2). It is a virtue of this collection that it draws attention to the connection between transcendental character of phenomenological inquiries and new other transcendental topics, including the temporal development of personhood, mortality and generativity, animality, and materiality (Heinämaa, Hartimo, Miettinen, 2014, 4).

Phenomenology and the Transcendental is an anthology of first-rate essays from key figures and several younger researchers in the field of phenomenological philosophy, each addressing "the concept of transcendental primarly in terms of a movement or a motive that does not simply leave behind the empirical reality but asks for its conditions of possibility in the experiencing subject, its correlates, and its manifold intentional layers" (Heinämaa, Hartimo, Miettinen, 2014, 11). The fourteen chapters are separated topically in four parts: Part I - Transcendental Phenomenology, Part II - Subjectivity and Intersubjectivity, Part III - Mind and the World, Part IV - Beyond Correlation. A helpful introduction by Sara Heinämaa, Mirja Hartimo, and Timo Miettinen provides a succinct overview of the individual pieces. As they make clear in the Introduction - Methodological, Historical, and Conceptual Starting Points, the present volume "brings together original articles that together clarify the transcendental aspects of phenomenology and outline new transcendental versions of phenomenology in distinction from the naturalistic, vitalist, and poststructuralist approaches that dominate philosophy at the moment" (Heinämaa, Hartimo, Miettinen, 2014, 3).

The first part, Transcendental Phenomenology, comprises only three essays ("Transcendental Life" by Steven Crowell, "Categories of Experience and the Transcendental" by László Tengelyi, and "The Transcendental Nature of Experience" by Bernhard Obsieger) and includes principled interpretations of the nature of transcendental phenomenology, its main variations, and its relation to the tradition of transcendental philosophy. Steven Crowell examines first Husserl's and Heidegger's investigations on the nature of transcendental phenomenology, arguing that genuine transcendental philosophy proves to be indispensable for the analysis of life "as the unhintergehbar horizon of all inquiry" (Heinämaa, Hartimo, Miettinen, 2014, 36). Crowell argues that "the intented move beyond transcendental phenomenology is il-

2 See especially Halla Kim, Steven Hoeltzel (2016). 
lusory: either it is no longer phenomenological, or else it fails to account for crucial features of the "life' that is ours" (Heinämaa, Hartimo, Miettinen, 2014, 36). László Tengelyi compares Kant's and Husserl's notions of transcendental in order to show that "transcendental arguments can be integrated into a phenomenological investigations on the categories of experience, provided that they are founded on 'subjectively necessary transcendental presuppositions' of reflective judgements" (Heinämaa, Hartimo, Miettinen, 2014, 59). Bernhard Obsieger closes this part by exploring how "our experience is not understood as a process that occurs within the world but as a process in which the world itself presents to us, and the subject is not understood as existing within the world but as the subjective correlate of the world as it appears from the experiential first-person point of view" (Heinämaa, Hartimo, Miettinen, 2014, 61).

The second part, Subjectivity and Intersubjectivity, consists of four essays ("Transcendental Subjectivity and the Human Being" by Hanne Jacobs, "Husserl on the Factical and Historical Grounds of the Transcendental Subject" by Simo Pulkkinen, "The Animal and the Infant: From Embodiment and Empathy to Generativity" by Sara Heinämaa, and "Transcendental Social Ontology" by Timo Miettinen) and clarifies the structures of transcendental subjectivity and intersubjectivity and the Husserlian concepts of activity and passivity. The essays in this section demonstrate that transcendental phenomenology is not mere epistemology but also examines dependencies that are relevant to social philosophy, political philosophy and ethics.

Hanne Jacobs explores Husserl's paradox of human subjectivity understood as "being a subject for the world and at the same time being an object in the world" (Husserl, 1988, 178-181). Drawing on Husserl's account of the distinction between the human being in the lifeworld and the human being as approached by natural science, Jacobs argues "for the need for a more developed personalistic account of the embodied person" (Heinämaa, Hartimo, Miettinen, 2014, 88). Simo Pulkkinen argues that "for Husserl, transcendental subjectivity and its constitutive functioning are from the ground up determined by a radical historicity and facticity" (Heinämaa, Hartimo, Miettinen, 2014, 107). By focusing especially on Husserl's analyses of the passive substratum of conscious life and on the dynamic, reciprocal interplay of preconstitution and pregivenness with the higher-level of conscious activities, Pulkkinen suggests that "transcendental subjectivity is determined by dynamic historicity starting from its most primordial and fundamental levels" (Heinämaa, Hartimo, Miettinen, $2014,107)$. Sara Heinämaa tries to analyse how human-animal contrast functions in Husserl's account of the constitution of the sense of the true world, that is the cultural-historical world. The overall purpose of this chapter is to clarify the nature-culture divide in Husserl's phenomenology of generative communities. Timo Miettinen dis- 
cusses the possibility of reinstituting "the relevance of transcendental philosophy for social ontology" (Heinämaa, Hartimo, Miettinen, 2014, 147). According to Miettinen, Husserl's philosophy of intersubjectivity based on the idea of a "transcendental we" (transzendentale Wir) provides us with rich dynamic of communal existence, one that is able to afford communities as certain transcendental status.

The third part, Mind and the World, comprises four essays ("The Emergence and Transformation of Husserl's Concept of World" by David Carr, "Phenomenological Sources, Kantian Borders: An Outline for Transcendental Philosophy as Object-Guided Philosophy" by Sophie Loidolt, "The Bodily Feeling of Existence in Phenomenology and Psychoanalysis" by Joona Taipale, and "William James on Consciousness and the Brain: From Psycho-Physical Dualism to Transcendental Philosophy" by Richard Cobb-Stevens) and explores the concepts of the world and the body and the role of the object in transcendental phenomenology.

David Carr traces the emergence and the subsequent transformations of Husserl's conception of the world. Carr's profound revisitation of these transformations allow us to "better understand Husserl's phenomenological method and the kinds of transcendental inquiries that it makes possible" (Heinämaa, Hartimo, Miettinen, 2014, 176). Sophie Loidolt compares Kant's account of simple (schlicht) and basic objectivity linked to subjective conditions of experience with Husserl's exploration of transcendental structures with the aim of "capturing the main Kantian ideas for an object-guided transcendental philosophy" (Transzendentalphilosophie vom Gegenstand her). By "object-guided", Loidolt means "a constant orientation along the character of givenness of objectivity and the objective world that is simple and straightforward, even if the analysis of its constitution brings to light a complex structure" (Heinämaa, Hartimo, Miettinen, 2014, 193). Joona Taipale juxtaposes what Freud, together with his successors, calls the body-ego (Körper-Ich) with the Husserlian lived-body in order to illustrate "how psychoanalysis, a particular nontranscendental discipline, may challenge and complement phenomenology" (Heinämaa, Hartimo, Miettinen, 2014, 219). Richard Cobb-Stevens closes the third part and outlines some important similarities and differences between Husserlian phenomenology and William James's account of the complementary contributions of mind and body to our cognitive and affective modes of consciousness.

The fourth and final part, Beyond Correlation, comprises three essays ("What is a Transcendental Description?" by Fredrik Westerlund, "Transcendental Idealism and Strong Correlationism: Meillassoux and the End of Heideggerian Finitude" by Jussi Backman, and „Die Kehre spielt im Sachverhalt selbst': Making Sense of the Twists and Turns in Heidegger's Thought" by Niall Keane), and discusses recent criticism 
that motivate the move beyond transcendental phenomenology and demonstrates this move cannot mean a step back to pretranscendental inquiries but must rather proceed forward. Rather than naturalizing phenomenology or inserting phenomenological inquiries into some positive ontology, this last part of the volume argues that transcendental philosophy can and must be developed by a radicalization of its questions.

The goal of Fredrik Westerlund's chapter is to revisit the sense of transcendental descriptions by discussing two doubts against this kind of procedure: essentialism and subjectivism. Westerlund shows how "transcendental descriptions cannot and need not involve any notion of transcendental subjectivity as their basic field of description or any ambition to establish the essential transcendental structures necessarily constituting different kinds of experince" (Heinämaa, Hartimo, Miettinen, 2014, 272). Jussi Backman reconstructs Meillassoux's critique of the main correlationist positions available since Kant's "Copernican revolution". As Backman clarifies, Meillassoux's reading of Heidegger as a strong correlationist is of key importance to his own project of "speculative materialism". Backman concludes with some remarks on the speculative "end of finitude" as a "way out of the final outcome of the heritage of transcendental idealism, or from contemporary 'postmodern' impasse in which the deabsolutization of thinking culminates in its deuniversalization" (Heinämaa, Hartimo, Miettinen, 2014, 288). Niall Keane make sense of the "twists and turns in Heidegger's Denkbewegung as responses to the twists and turns in being itself" (Heinämaa, Hartimo, Miettinen, 2014, 311). Keane argues that the "turn" (Kehre) unfolds as a topical motive in Heidegger's philosophy, and this motive explains the transition from the existential analytic of Dasein toward the history of being

As a final aside, it is worth noting that every part of this collection is stimulating and rich in useful insights about the transcendental heritage in phenomenology. This edited collection will be of interest to philosophers working on the post-Kantian transcendental tradition, traditional forms of transcendental philosophy, and post-transcendental phenomenology.

\section{REFERENCES}

Da Silva, J.J. (2017). Mathematics and Its Applications. A Transcendental-Idealist Perspective. Switzerland: Springer.

Engelland, C. (2017). Heidegger's Shadow: Kant, Husserl, and the Transcendental Turn. New York: Routledge.

Gardner S., \& Grist, M.(Eds.). (2015). The Transcendental Turn. Oxford: Oxford University Press.

Heinämaa, S., Hartimo, M., Miettinen, T. (Eds.). (2014). Phenomenology and the Transcendental. New York: Routledge. 
Honenberger, P. (Ed.). (2016). Naturalism and Philosophical Anthropology: Nature, Life, and the Human between Transcendental and Empirical Perspectives. London: Palgrave Macmillan.

Husserl, E. (1988). The Crisis of European Sciences and Transcendental Phenomenology: An Introduction to Phenomenological Philosophy. Evanston: Northwestern University Press.

Kim, H., \& Hoeltzel, S. (Eds.). (2016). Transcendental Inquiry: Its History, Methods and Critiques. London: Palgrave Macmillan.

Luft, S. (2011). Subjectivity and Lifeworld in Transcendental Phenomenology. Evanston: Northwestern University Press.

Staiti, A. (2014). Husserl's Transcendental Phenomenology: Nature, Spirit, and Life. Cambridge: Cambridge University Press.

Zahavi, D. (2017). Husserl's Legacy: Phenomenology, Metaphysics, and Transcendental Philosophy. Oxford: Oxford University Press. 